Fifi Widyaningsih dan Supri Wahyudi Utomo : Pengaruh Good Corporate Governance ...

\title{
PENGARUH GOOD CORPORATE GOVERNANCE DAN STRUKTUR KEPEMILIKAN TERHADAP KINERJA PERUSAHAAN (STUDI EMPIRIS PADA PERUSAHAAN MANUFAKTUR YANG TERDAFTAR DI BEI TAHUN 2010-2011)
}

\author{
Fifi Widyaningsih \\ Supri Wahyudi Utomo \\ Pendidikan Akuntansi IKIP PGRI MADIUN
}

\begin{abstract}
This study aims to investigate the influence of good corporate governance and ownership structure of the company to increase the performance of the company. This study uses secondary data, the annual financial statements of a manufacturing company that has been listed on the Indonesia Stock Exchange for the years 2010-2011. The sampling used in this study is purposive sampling. Analyze by multiple regression analysis. The results of multiple linear regression analysis in this study is that corporate governance has a positive effect on company performance, while the shareholding structure of the institutional ownership either managerial or no positive effect on company performance.
\end{abstract}

\begin{abstract}
ABSTRAK
Penelitian ini bertujuan untuk meneliti pengaruh good corporate governance dan struktur kepemilikan saham dalam perusahaan terhadap peningkatan kinerja perusahaan. Penelitian ini menggunakan data sekunder, yaitu laporan keuangan tahunan perusahaan manufaktur yang telah terdaftar di Bursa Efek Indonesia untuk tahun 2010-2011. Pengambilan sampel yang digunakan dalam penelitian ini adalah purposive sampling. Analisis data dengan analisis regresi berganda. Hasil analisis regresi linier berganda dalam penelitian ini adalah corporate governance memiliki pengaruh yang positif terhadap kinerja perusahaan, sedangkan struktur kepemilikan saham baik kepemilikan dari pihak institusional ataupun manajerial tidak berpengaruh positif terhadap kinerja perusahaan.
\end{abstract}

\section{PENDAHULUAN}

Penelitian terhadap praktik-praktik bisnis di Indonesia merupakan sesuatu yang menarik jika dilihat dari posisi Indonesia sebagai negara yang merupakan salah satu negara terbesar di dunia bila dilihat dari segi luas wilayah, jumlah populasi maupun sumber daya yang dimiliki. Perekonomian Indonesia saat ini masih tergolong berkembang begitupun untuk pasar modalnya, akan tetapi saat ini adanya kemajuan dari ledakan pertumbuhan saham-saham yang terdaftar di Bursa Efek Indonesia yang dramatis dapat dilihat dari pertumbuhan di pasar sekunder. Untuk kegiatan dari pihak perusahaan yang berupa pendanaan melalui mekanisme penyertaan, dilakukan dengan menjual saham perusahaan kepada masyarakat atau sering dikenal dengan go public. Perusahaan go public membutuhkan pengelolaan corporate governance yang baik atau yang lebih dikenal dengan good corporate governance. 
Menurut pendapat Arief (2008: 2), good corporate secara singkat dapat diartikan sebagai seperangkat sistem yang mengatur dan mengendalikan perusahaan untuk menciptakan nilai tambah (value added) bagi para pemangku kepentingan yang mempengaruhi kinerja perusahaan. Selama sepuluh tahun ini istilah GCG sangat populer bahkan menjadi sesuatu yang terhormat, pertama good corporate governance adalah salah satu pilar dalam sistem ekonomi pasar, bahkan dengan menerapkan GCG secara baik diyakini dapat menolong perusahaan dan perekonomian negara yang sedang tertimpa krisis untuk bangkit menuju ke arah yang lebih sehat dan perusahaan yang menerapakan GCG juga mampu bersaing mengelola secara dinamis serta profesional.

Teori Agency Jensen dan Meckling 1976 dalam (Rafrini, 2012: 1), menyatakan bahwa adanya sebuah kontrak antar principal (pemilik/pemegang saham) dan agen (manajer/pengelola) yang mana baik pemilik dan pengelola merupakan pemaksimum kesejahteraan. Menurut pendapat Arifin (2005: 5), menurut teori ini hubungan antara pemilik dan manajer pada hakekatnya sukar tercipta karena adanya kepentingan yang saling bertentangan (confllict of interest). Dengan adanya itu maka penerapan good corporate governance diharapkan mampu mengurangi masalah keagenan yang terjadi sehingga kinerja suatu perusahaan dapat berjalan baik

Berdasarkan uraian di atas, maka penelitian ini mengambil judul

"Pengaruh Good Corporate Governance dan Struktur Kepemilikan terhadap Kinerja Perusahaan".

Berdasarkan uraian diatas maka penulis menguraikan permasalahannya sebagai berikut :

1. Apakah terdapat pengaruh positif antara good corporate governance dengan kinerja perusahaan?

2. Apakah terdapat pengaruh positif antara struktur kepemilikan dengan kinerja perusahaan?

3. Apakah ada pengaruh antara good corporate governance dan struktur kepemilikan secara simultan terhadap kinerja perusahaan.

\section{KAJIAN PUSTAKA}

\section{Good Corporate Governance Dan Struktur Kepemilikan}

Good corporate governance (GCG) secara singkat dapat diartikan seperangkat sistem yang mengatur dan mengendalikan perusahaan untuk menciptakan nilai tambah (value added) bagi para pemangku kepentingan. Hal ini disebabkan karena GCG dapat mendorong terbentuknya pola kerja manajemen yang bersih, transparan, dan professional (Arief Efendi, 2009: 2). Corporate governance dapat didefinisikan sebagai suatu proses dan struktur yang digunakan oleh organ perusahaan (pemegang saham/pemilik modal, komisaris/dewan pengawas dan direksi) untuk meningkatkan keberhasilan usaha dan akuntabilitas perusahaan guna mewujudkan nilai pemegang saham dalam jangka panjang dengan tetap memperhatikan kepentingan stakeholder lainnya, berlandaskan peraturan perundang-undangan dan nilai-nilai etika Adrian Sutedi, (2011: 1). Stuktur kepemilikan adalah suatu mekanisme yang dapat mengurangi konflik antara manajemen dan pemegang saham sehingga agency cost dapat dikurangi dengan adanya struktur kepemilikan (Faisal, 2004: 1). 
Fifi Widyaningsih dan Supri Wahyudi Utomo : Pengaruh Good Corporate Governance ...

\section{Kinerja Perusahaan}

Penilaian kinerja adalah penentuan secara periodik efektivitas operasional suatu organisasi, bagian organisasi dan karyawan berdasarkan sasaran, standar dan kinerja yang telah ditetapkan sebelumnya. Penilaian kinerja perusahaan dapat dilihat dari segi analisis laporan keuangan dan dari segi perubahan harga saham (Anindhita, 2011:21).

\section{HIPOTESIS}

Hipotesis penelitian yang dirumuskan sebagai berikut:

H1 : Adanya pengaruh positif good corporate governance terhadap kinerja perusahaan (ROA).

$\mathrm{H} 2 \mathrm{a}$ : Adanya pengaruh positif antara kepemilikan manajerial terhadap kinerja perusahaan (ROA).

$\mathrm{H} 2 \mathrm{~b}$ : Adanya pengaruh positif antara kepemilikan institusional terhadap kinerja Perusahaan (ROA).

H3 : Good corporate governance dan struktur kepemilikan secara simultan berpengaruh positif terhadap kinerja perusahaan.

\section{METODOLOGI PENELITIAN}

Populasi penelitian ini adalah perusahaan-perusahaan manufaktur yang terdaftar di Bursa Efek Indonesia (BEI) pada tahun 2010 sampai tahun 2011.

Penentuan sampel dilakukan menggunakan metode purposive sampling yaitu metode pengambilan sampel berdasarkan kriteria tertentu. Jumlah sampel yang digunakan sebanyak 81 perusahaan manufaktur yang terdaftar di BEI dengan jumlah sampel data sebanyak 152 perusahaan dengan tahun pengamatan 2010 dan 2011, Adapun kriteria yang digunakan dalam pengambilan sampel yaitu:

a. Perusahaan manufaktur yang terdaftar di BEI dari tahun 2010 dan 2011.

b. Tidak keluar (delisting) dari BEI selama periode penelitian (tahun 2010 dan 2011).

c. Menerbitkan laporan keuangan tahunan (annual report) yang berakhir pada tanggal 31 Desember selama periode pengamatan 2010 dan 2011.

d. Perusahaan memiliki data yang lengkap terkait dengan variabel-variabel yang digunakan dalam penelitian.

\section{Metode Pengumpulan Data}

Dalam penelitian ini mengunakan sumber data sekunder. Data sekunder dalam penelitian ini diperoleh kuantitatif yang diperoleh dalam penelitian ini data dari Pusat Refrensi Pasar Modal BEI, yang berupa laporan keuangan yang diterbitkan perusahan-perusahaan yang terdaftar di BEI. Data yang digunakan meliputi :

1) Data perkembangan saham tahun 2010 dan 2011.

2) Laporan keuangan tahun 2010 dan 2011 perusahaan manufaktur yang terdaftar di BEI. 


\section{Teknik Analisis Data}

\section{Uji Asumsi Klasik}

\section{a. Uji Normalitas}

Uji normalitas bertujuan untuk menguji apakah model regresi, variable penggangu atau residual mempunyai distribusi normal atau tidak. Pengujian normalitas data dilakukan menggunakan kurva normal probability plot dengan ketentuan jika titik-titik pada grafik menyebar dan berhimpit mengikuti sekitar garis diagonal maka data yang digunakan berdistribusi secara normal.

Hasil kurva normal probability plot memperlihatkan bahwa titik-titik pada grafik terlihat menempel dan mengikuti garis diagonalnya, sehingga berdasarkan kurva normal probability plot, data yang digunakan berdistribusi normal.

b. Uji Heteroskedastisitas

Uji Heteroskedastisitas digunakan untuk mengetahui apakah model regresi terjadi ketidaksamaan varians dari residual satu pengamatan ke pengamatan yang lain (Ghozali, 2012: 139).

Grafik scatter plots memperlihatkan bahwa titik-titik pada grafik tidak bisa membentuk pola tertentu yang jelas, dimana titik-titik menyebar di atas dan di bawah angka 0 pada sumbu Y, sehingga grafik tersebut tidak bisa dibaca dengan jelas. Hasil ini memperlihatkan bahwa tidak terjadi heteroskedastisitas.

c. Uji Autokorelasi

Uji asumsi ini dimaksudkan untuk mengetahui apakah dalam model regresi linier terjadi korelasi antara variabel. Sebab adanya autokorelasi mengakibatkan penaksir mempunyai varian tidak minimum dan uji t tidak dapat digunakan, karena memberikan kesimpulan yang salah. Pengujian ini dilakukan dengan uji Durbin-Watson (DW Test). Keputusan ada tidaknya autokorelasi dapat ditentukan dengan melihat posisi nilai DW. Jika nilai dU $<\mathrm{d}<4-\mathrm{Du}$, maka tidak terjadi autokorelasi.

Berdasarkan hasil uji autokorelasi menunjukkan nilai DW sebesar 1,976 dengan taraf signifikansi 5 persen, untuk $\mathrm{N}=152$ jumlah variabel bebas sebanyak 3 dan $\alpha=0,05$ diperoleh nilai du sebesar 1.7752. Oleh karena nilai $\mathrm{dw}$ berada pada $\mathrm{du}<\mathrm{dw}<4-\mathrm{du}$, berarti tidak terdapat autokorelasi sehingga model ini layak digunakan untuk analisis selanjutnya.

\section{d. Uji Multikolinieritas}

Uji multikolinieritas bertujuan untuk menguji apakah model regresi ditemukan adanya korelasi antar variabel bebas (independen). Jika nilai Tolerance lebih dari 0,1 atau nilai VIF kurang 10 maka hal tersebut menunjukkan tidak terjadi multikolinearitas. Dari pengujian multikolinieritas nilai VIF kurang dari 10 dan nilai tolerance lebih dari 0,1 untuk kedua variabel, maka dapat disimpulkan bahwa model regresi tidak terjadi masalah multikolinieritas.

\section{Pengujian Model Analisis Linier Berganda}


Fifi Widyaningsih dan Supri Wahyudi Utomo : Pengaruh Good Corporate Governance ...

Teknik analisa ini digunakan untuk ménge tahü besarnya pengarüh antara good corporate governance, struktur kepemilikan institusional, struktur kepemilikan manajerial terhadap kinerja perusahaan. Dalam penelitian ini, hasil regresi menggunakan standardized coefficients. Persamaan liniear dari hasil regresi yang didapat adalah $\mathrm{Y}=0,977 \mathrm{X}_{1}-0,389 \mathrm{X}_{2}-0,172 \mathrm{X}_{3}$

Pada persamaan regresi tersebut, koefisien regresi semua variabel independen tidak berpengaruh positif terhadap kinerja perusahaan. Dari hasil koefesien regresi yang didapat menunjukkan, faktor GCG $\left(\mathrm{b}_{1}=0,977\right)$ menjadi faktor terbesar yang mempengaruhi kinerja perusahaan, kemudian untuk struktur kepemilikan institusional $\left(b_{2}=-0,389\right)$ dan struktur kepemilikan manajerial $\left(b_{3}=-0,172\right)$ tidak mempengaruhi kinerja perusahaan.

\section{Pengujian Hipotesis}

\section{a. Pengujian secara parsial (uji - t)}

Uji - $\mathrm{t}$ ini digunakan untuk membuktikan adanya pengaruh yang signifikan antara GCG dan Struktur kepemilikan terhadap kinerja perusahaan. Pengujian hipotesis secara parsial dari variabel independen yang meliputi good corporate governance, struktur kepemilikan dan kinerja perusahaan. Good Corporate Governance berpengaruh positif terhadap kinerja perusahaan (uji-t $=2,868$ dengan sig. 0,05 ), struktur kepemilikan institusional dan untuk struktur kepemilikan manajerial tidak berpengaruh positif terhadap kinerja perusahaan dengan (uji- $\mathrm{t}=1,185$ ) untuk kepemilikan institusional dan (uji- $\mathrm{t}=-1,022$ ) untuk kepemilikan manajerial.

\section{d. Pengujian secara Silmutan (Uji F)}

Model regresi linear berganda ini digunakan untuk membuktikan variabel good corporate governance, struktur kepemilikan berpengaruh secara individu pada kinerja perusahaan manufaktur yang diukur dengan ROA. Hasil pengolahan data terlihat bahwa nilai $F=3,254$ dengan probabilitas sebesar 0,023 . Nilai signifikansi yang lebih kecil dari 0,05 menunjukkan bahwa kinerja perusahaan ROA dapat dijelaskan oleh struktur kepemilikan manajerial, struktur kepemilikan institusional dan GCG.

\section{e. Koefisien Determinasi}

Koefisien determinasi digunakan untuk mengetahui kemampuan variabel independen dalam menjelaskan variabel dependen. Besarnya koefesien determinasi dapat dilihat pada adjsuted $r$ square dan dinyatakan dalam presentase. Hasil koefisien determinasi antara good corporate governance, struktur kepemilikan instutusional, struktur kepemilikan manajerial terhadap kinerja perusahaan.

\section{Pembahasan}

\section{Good Corporate Governance}

Berdasarkan hasil penelitian diperoleh bahwa good corporate governance berpengaruh terhadap kinerja perusahaan Hasil ini sesuai dengan hipotesis 1, bahwa good corporate governance memiliki pengaruh positif terhadap kinerja perusahaan. Penelitian ini menunjukkan bahwa pengungkapan corporate governance yang diproksikan dengan index GCG pada kinerja perusahaan yang 
dibuktikan dengan koefisien sebesar 2,868 dengan tingkat signifikansi sebesar 0,005 .

\section{Struktur Kepemilikan}

Berdasarkan hasil penelitian diperoleh bahwa struktur kepemilikan baik institusional ataupun manajerial tidak berpengaruh terhadap kinerja perusahaan. Hasil ini tidak sesuai dengan hipotesis 2, bahwa struktur kepemilikan memiliki pengaruh positif terhadap kinerja perusahaan. Hal ini mungkin didasarkan pada terjadinya conflict of interest antara manajemen perusahaan dengan stockholder. Stockholder menghendaki pola pengelolaan perusahaan untuk dapat memberi kontribusi yang besar bagi dana yang diinvestasikannya ke dalam perusahaan. Keuntungan yang diperoleh perusahaan diarahkan pada investasi yang menghasilkan present value yang positif. Sedangkan disisi lain manajemen berusaha untuk mengelola perusahaan sebaik mungkin untuk memperoleh bonus yang besar.

\section{Kesimpulan} berikut :

Kesimpulan yang dapat diperoleh dari hasil penelitian ini adalah sebagai

1. Berdasarkan hasil penelitian diperoleh bahwa Good Corporate Governance secara statistik berpengaruh positif terhadap kinerja perusahaan. Hasil tersebut menunjukkan bahwa penerapan corporate governance yang efektif akan dapat meningkatkan kinerja perusahaan.

2. Berdasarkan hasil penelitian diperoleh bahwa struktur kepemilikan baik kepemilikan institusional ataupun kepemilikan manajerial tidak berpengaruh positif terhadap kinerja perusahaan hal ini dikarenakan adanya perbedaan kepentingan antara pihak manajerial dengan pihak institusional (stakeholder) sehingga kebijakan yang seharusnya diterapkan tidak dihiraukan dalam proses pengelolaan kinerja perusahan.

\section{Keterbatasan dan Saran}

Adanya keterbatasan pengggunaan rasio profitabilitas ROA yang lebih cenderung berfokus untuk tujuan jangka pendek bukan jangka panjang dan fokus pada penelitian perusahaan manufaktur dengan kategori tahun yang diteliti dua tahun yaitu 2010-2011, maka untuk memperoleh perbandingan dalam pengukuran kinerja perusahaan, peneliti yang akan melakukan penelitian sejenis selanjutnya dapat menambahkan jenis rasio lain dalam mengukur kinerja

\section{DAFTAR PUSTAKA}

Adrian Sutedi. 2011. Good Corporate Governance. Jakarta: Sinar Grafika.

Andiany Indra Pujiningsih. 2011. "Pengaruh Struktur Kepemilikan, ukuran perusahaan, praktik Corporate governance dan kompensasi bonus terhadap manajemen laba". Skripsi 1-79, (diunduh 21 Februari 2013).

Anindhita Ira Sabrinna. 2010. "Pengaruh Corporate Governance Dan Struktur Kepernilikan Terhadap Kinerja Perusahaan”. (Online), (http://eprints.undip.ac.id, diunduh 1 Juli 2012). 
Fifi Widyaningsih dan Supri Wahyudi Utomo : Pengaruh Good Corporate Governance ...

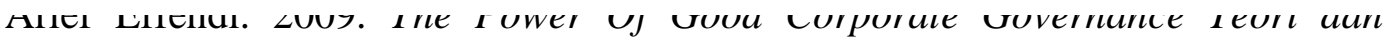
Implementasi. Jakarta: Salemba Empat.

Arifin. 2005. “Peran Akuntansi Dalam Menegakkan Prinsip Good Corporate Governance Pada Perusahaan di Indonesia (Tinjuan Perspektif Teori Keagenan)”. Sidang Senat. (diunduh 28 Maret 2013).

Faisal. 2005. "Analisis Agency Cost, Struktur Kepemilikan dan Mekanisme Corporate Governance". Jurnal Riset Akuntansi, Vol 8 No 2.(diunduh 21 Februari 2013).

Kenneth, Kim. 2007. Corporate Governance. America: Pearson. Larcker, Richardson. and Tuna. 2007. "Corporate Governance, Accounting Outcomes, and Organizational Performance". The Accounting Review, Vol. 82, No. 42007 pp. 963-1008.(http://vwll.ets.kit, diunduh 27 Februari 2013).

Luciana Spica Almilia, Lailul L. Sifa. 2006. "Reaksi Pasar Publikasi Corporate Governance Index Pada Perusahaan yang Terdaftar di Bursa Efek Jakarta". SNA Makasar, 26-28 Juli 2007.(diunduh 21 Februari 2013).

Marihot Nasution dan Doddy Setiawan. 2007." Pengaruh Corporate Governance Terhadap Manajemen Laba Di Industri Perbankan Indonesia”. SNA X 2628 Juli. (diunduh 27 Februari 2013).

Rafrini Amyulianthy. 2012.'Pengaruh struktur corporate governance terhadap kinerja perusahaan publik Indonesia". Jurnal liquidity. Vol 1 no 2, Juli Desember. (diunduh 21 Februari 2013).

Sawitri Sekaredi. 2011. "Pengaruh Corporate Governance terhadap Kinerja keuangan perusahaan”. Skripsi. (diunduh 27 Februari 2013). Sedarmayanti. 2012. Good Governance dan Good Corporate Governance. Jakarta CV Mandar Maju.

Sri Trisnaningsih. 2007. "Tndependensi Auditor dan Komitmen Oganisasi ebagai Mediasi Pengaruh Pemahaman Good Corporate, Gayya Kepemimpinan, dan Budaya Organisasi Terhadap Kinerja Auditor". SNA X UNHAS Makasar, (diunduh 27 Februari 2013).

Sugiarto. 2009. Struktur Modal, Struktur Kepemilikan Perusahaan, Permasalahan Keagenan, Dan Informasi Asimetni. Yogyakarta: Graha Ilmu.

Sugiyono. 2011. Metode Penelitian Kuantitatif, Kualitatif, dan R\&D. Bandung: Alfabeta.

Supatmi. 2007. "Corporate Governance Dan Kinerja Keuangan”. Jurnal Bisnis dan Ekonomi (Online), Vol. 14, 2007. (http://www.unisbank.ac.id, Diunduh 23 Februari 2013). 
Suryo Pratolo. 2007. " Aspek Audit Manajemen dan Ppengendalian Intern Sebagai Variabel Eksogen Serta Tinjauan Pada Jenis Perusahaan “, SNA Makasar, 26-28 Juli 2007. (diunduh 27 Februari 2013). 